\title{
Primary Energy Consumption Structure and The Influencing Factors In China: An Income Decomposition and Post-Economic Crisis Era Perspective
}

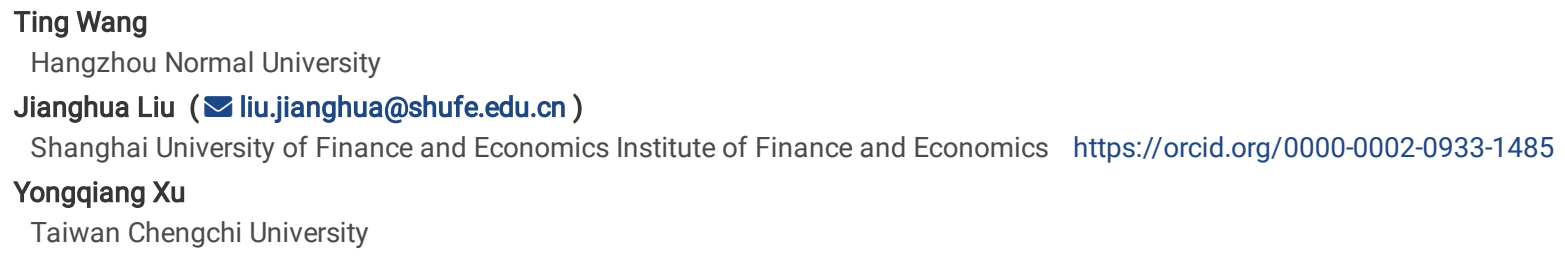

\section{Research Article}

Keywords: Energy consumption structure, Income structure, Panel data, Primary energy structure, coal-based energy structure, Decomposition methodology Posted Date: December 28th, 2021

DOI: https://doi.org/10.21203/rs.3.rs-1112573/v1

License: () (i) This work is licensed under a Creative Commons Attribution 4.0 International License. Read Full License 


\section{Abstract}

China's coal-based energy structure makes its carbon peak and neutrality goals very challenging. Therefore, the optimization of the energy structure has become an important means, and exploring its influencing factors and trends has become the basis and prerequisite for the formulation of policies related to the optimization of the energy structure. This study adopts regression methods considering heteroskedasticity and cross-section correlation to study the panel data of 30 provinces in China, and obtains the changes of relationship between the fossil and non-fossil fuels consumption of different regions and their influencing factors after two global financial crises. Research results show that, China's energy consumption tends to decouple from GDP. Income structure changes especially trade changes are important factors in influencing energy consumption and energy structure. The deviation of energy resources distribution and consumption distribution tends to strengthen. The impact of urbanization development models, energy prices and efficiency shows regional heteroskedasticity.

\section{Introduction}

With the development of low-carbon economy, governments are paying more and more attention to the optimization of energy structure. Due to the characteristics of resource endowment, China's energy consumption has long been dominated by coal. Therefore, the optimization of energy consumption structure has attracted much attention today due to the increase of environmental pressure. Chinese government has continuously introduced policies to encourage the development and utilization of new energy sources, and to optimize energy structure and reduce pollutant emissions through technologies and policies. However, due to the characteristics of the development stages of urbanization and industrialization, such as the economic characteristics of investment-driven and administrative guidance, may offset the effects of these policies; On the other hand, there are significant regional differences in economic development in China, and there is a certain imbalance between the distribution of energy resources and energy consumption. Figure 1 , Figure 2 and Figure 3 show the changes in China's primary energy structure, the primary energy consumption structure of 30 provinces in China, and the resource endowments in each region. The combination of the three figures shows that there are huge differences in energy consumption and resource endowment in different regions, and it is necessary to optimize relevant energy consumption policies. As Zhang and Lahr (2014) said: as a spatially large and heterogeneous country, it is crucial to identify the key driving forces of the growth in energy use for each region to design appropriate regional energy conservation policies.

Based on existing research and understanding of China's energy consumption and regional differences, this study will comprehensively consider macro-level factors, including income, income structure, urbanization, energy price and efficiency, from the perspective of geographic location and economic development similarity, using regional panel data and regression models to study the relationship between these factors and the main primary energy consumption, the differences before and after economic crisis and then draws some policy implications.

The other parts of the paper are arranged as follows: the second part is a literature review. Based on the literature review, the variables, research methods and data used in the empirical tests are introduced in the third part. The empirical research results and discussion are given in the fourth part, and the fifth part encapsulates the main points of the study and gives some policy implications.

\section{Literature Review}

\subsection{Literature Review on Influencing Factors of Energy Consumption and Emissions}

At present, most of the literature on energy consumption research studies the total energy consumption or a certain kind of energy consumption, and most of these literature focus on the relationship between energy consumption and its influencing factors (Zou and Chau 2006; Aydin 2014; Zhang and Cheng 2009; Oh and Lee 2004; Kankal et al. 2011). Many researches take technological progress, economic growth, energy price and regulatory mechanism as important factors to study energy demand or energy intensity, or related emissions. Income variables represented by GDP are widely used (Mahalingam and Orman 2018; Wang and Lin 2017; Tugcu and Topcu 2018). They usually ignore the impact of structural changes. However, changes in both the income structure and the energy structure may affect their relationship (Omri 2014; Zoundi 2017).

\subsection{Literature review on energy structure}

There is relatively little direct research on the structure of energy consumption in the academic community. There are also some studies involving energy consumption in different categories (Wang and Lin 2017; Wandji 2013; Bilgen 2014; Park and Hong 2013; Tugcu and Topcu 2018; Saboori and Sulaiman 2013), but they rarely directly discuss energy structure. Many studies have focused on the impact of energy structure on energy efficiency and carbon emission efficiency (Chen and Chen 2016; Wang and Xie 2015; Liu et al. 2016; Zhang et al. 2016; Chen et al. 2018). The above-mentioned studies mostly focus on the relationship between energy structure and energy efficiency, carbon emissions, etc., and seldom directly study energy structure and its influencing factors. The research on China's energy consumption is mainly about primary energy consumption, terminal energy consumption or a specific energy consumption, rarely involving changes in energy structure. As Liao and Wei (2010) said: Most previous studies directly used the aggregate energy data provided by China's National Bureau of Statistics or International Energy Agency, and this approach sometimes may be not scientific when we want to precisely investigate the energy-economy interactions. Research involving the structure of energy consumption, either using a grey model (Li et al. 2006; Tsai 2016; Yuan et al. 2010) or studying the energy consumption structure of certain production sectors (Wei et al. 2007; Zhou et al. 2009). Some researchers also studied energy consumption or energy intensity of China in different categories (Chang et al. 2003; Fan et al. 2007; Yuan et al. 2008; Fan and Xia 2012; FisherVanden et al. 2004; Feng et al. 2009), however, they have rarely considered the issue of energy consumption structure, especially the structure of fossil energy consumption.

\subsection{Literature review on energy consumption and financial crisis}


In recent decades, two major economic crises, including the 1998 economic crisis and the 2008 economic crisis, have had a profound impact on the global economy. Some scholars have also paid attention to the relationship between the economic crisis and energy consumption.

By using a Multi-scale Integrated Analysis of Societal and Ecosystem Metabolism, Andreoni (2020) investigated energy requirements, economic trends and population for the years 2008 and 2015, and discussed how the deceleration of economic growth, that followed the financial crisis of 2008, influenced the energy efficiency, allocation and use of 18 European countries. Andriosopoulos et al. (2017) investigated if and to what extent events in financially troubled EU markets (Greece, Ireland and Portugal) affected energy prices during the EU financial crisis. Hofman and Huisman (2012) presented a research project that examined whether the preferences of investors in Europe and the U.S. changed due to the financial crisis and found that the popularity of 11 out of 12 policies decreased. Selcuk and Durusoy (2019) pointed that the transportation sector is an energy intensive sector, need more attention from policy makers due to its contribution to the increase in energy intensity after the crisis years, as well as its increasing contribution to overall energy intensity.

Some scholars have found that after the 2008 crisis, there have been a trend of decoupling between energy consumption or carbon emissions and GDP (Mentis et al. 2015; Sadorsky 2020).

For Asian countries, Setyawan et al. (2020), Bekhe and Yasmin (2014) and Lin (2010) have discussed the influence on energy consumption and economic growth of Global Financial Crisis.

As Timma et al. (2016) said: there is need to evaluate the effect of economy recession in other regions and countries. Moreover decomposition analysis can be further expanded to include the aggregate of energy carried in order to account for the shift towards renewable energy at sectorial level. We believe that the structure of the income is also important. In China, like the energy consumption structure, important changes are also taking place in the structure of various parts of the GDP in the macroeconomic body, especially after the 2008 global financial crisis. The changes in the overall environment have caused major changes in China's foreign trade environment, and exports have suffered more with big resistance, while imports have grown rapidly, as shown in Figure 4. In addition, in order to promote economic development, various regions have increased their investment. From the perspective of the GDP structure of expenditure method, as shown in Figure 5, the proportion of total capital formation in GDP has increased. However, few scholars have so far discussed the relationship between the changes in the proportion of expenditures of various sectors in the GDP of the expenditure method and energy consumption, especially the energy structure.

In this study, the primary energy structure in China is considered, and the relationship between coal, oil, natural gas and GDP would be studied respectively. At the same time, this paper also added the income structure as an influencing factor from the perspective of expenditure method of GDP accounting to discuss the relationship between it and energy consumption, and supplemented the existing research.

\section{Variables And Data}

From the method point of view, the panel data model is widely used in the study of energy consumption in different countries or regions (For example, Narayan and Popp 2012; Li and Lin 2015; Li et al. 2011; Wang and Lin 2019). Based on the literature, from the perspective of macroeconomics, the influencing factors of primary energy consumption generally include income, price, economic structure, population, and technical progress. Considering the representation and availability of data, the dependent variables and data selected in this paper are as follows: per capita total primary energy consumption (TOT), per capita coal consumption (COA), per capita oil consumption (OIL), per capita natural gas consumption (GAS), per capita other fuel consumption (OTH) which includes primary electricity and other non-fossil fuels. The energy consumption data are from NBSC (2018a).

Per capita GDP is also included. As GDP represented by expenditure includes household final consumption expenditure, capital formation, general government final consumption expenditure, exports and imports of goods and services. As the levels and shares of these variables in GDP reflect the region's economy and social structure characteristics, we use these variables to analyze the influence of income structure on energy consumption for better comparisons and understanding. These variables include per capita real GDP (GDP), household final consumption expenditure share in GDP (VCON), gross capital formation share in GDP (VINV), general government final consumer expenditure share in GDP (VGOV), exports of goods and services in GDP (VEXP), imports of goods and services share in GDP (VIMP), which are calculated by expenditure method can reflect economic structure. And the data are from NBSC (2018c) (constant $2008 \mathrm{RMB})$.

Urbanization rate (URR) is used to capture socio-demographic structure, and the data is from NBSC (2018b). Fuel Retail Price Index is used as price variable (EPR) (2008 as the base year), and the data is from NBSC (2018c). The fossil resource endowment coefficient is also introduced as a simple indicator of the energy supply capacity of the fossils in the region, and equals to fossil energy production/fossil energy consumption (REE), the data are from NBSC (2018a). The ratio of real GDP to electricity consumption is used as technology variable (EEF) or efficient variable (Chong et al. 2017), and the data are from NBSC (2018c). The definition of the specific variables used in this study, the unit measurements and the sources of the data are listed in Table 1. In order to avoid heteroscedasticity problem, the figures are transformed into logarithmic form. The logarithmic form is expressed as follows: LnTOT, LnCOA, LnOIL, LnGAS, LnOTH, LnGDP, LnSCON, LnSINV, LnSGOE, LnSEXP, LnSIMP, LnURR, LnREE, LnEPR, and LnEEF. And the time scale of the data is from 1998 to 2017 . Table 2 provides the statistical review of the variables. 
Table 1

Definition of the variables used in the study

\begin{tabular}{|c|c|c|c|}
\hline Variable & Definition & Units of measurement & Data source \\
\hline TOT & Per capita total primary energy consumption & Kilogram of oil equivalent & NBSC (2018a) \\
\hline \multirow[t]{2}{*}{$\mathrm{COA}$} & Per capita coal & Kilogram of oil equivalent & NBSC (2018a) \\
\hline & consumption & & \\
\hline OIL & Per capita oil consumption & Kilogram of oil equivalent & NBSC (2018a) \\
\hline GAS & Per capita natural gas consumption & Kilogram of oil equivalent & NBSC (2018a) \\
\hline OTH & Per capita other energy consumption & Kilogram of oil equivalent & NBSC (2018a) \\
\hline GDP & Per capita real GDP & Constant $2008 Y$ & NBSC (2018c) \\
\hline SCON & Share of household final consumption expenditure in GDP & $\%$ & NBSC (2018c) \\
\hline SINV & Share of gross capital formation in GDP & $\%$ & NBSC (2018c) \\
\hline SGOV & Share of general government final consumption expenditure in GDP & $\%$ & NBSC (2018c) \\
\hline SEXP & Share of exports of goods and services in GDP & $\%$ & NBSC (2018c) \\
\hline SIMP & Share of imports of goods and services in GDP & $\%$ & NBSC (2018c) \\
\hline URR & Urbanization rate & $\%$ & NBSC (2018c) \\
\hline REE & Endowment of fossil energy resources & NBSC (2018a) & \\
\hline EPR & Fuel Retail Price Index & 2008 as the base year & NBSC (2018c) \\
\hline EEF & Ratio of real GDP to electricity consumption & Constant $2008 Y_{/ k W h}$ & NBSC (2018c) \\
\hline
\end{tabular}


Table 2

Statistical reviews of variables

\begin{tabular}{|c|c|c|c|c|c|c|}
\hline Variable & & Mean & Std. Dev. & Min & Max & Observations \\
\hline \multirow[t]{3}{*}{ TOT } & overall & 1226.97 & 1591.43 & 4.09 & 9677.66 & $N=600$ \\
\hline & between & & 990.12 & 340.07 & 3897.24 & $\mathrm{n}=30$ \\
\hline & within & & 1258.34 & -2628.21 & 7703.90 & $T=20$ \\
\hline \multirow[t]{3}{*}{ OTH } & overall & 19.93 & 25.44 & 0.01 & 254.54 & $N=460$ \\
\hline & between & & 14.98 & 2.56 & 64.60 & $\mathrm{n}=30$ \\
\hline & within & & 21.58 & -41.61 & 209.86 & T-bar $=15.3333$ \\
\hline \multirow[t]{3}{*}{$\mathrm{COL}$} & overall & 860.88 & 1294.51 & 0.01 & 7965.65 & $N=600$ \\
\hline & between & & 883.54 & 274.3 & 3750.83 & $\mathrm{n}=30$ \\
\hline & within & & 959.11 & -2884.9 & 5075.7 & $\mathrm{~T}=20$ \\
\hline \multirow[t]{3}{*}{ OIL } & overall & 245.96 & 303.9 & 0 & 2335.34 & $N=545$ \\
\hline & between & & 190.36 & 0.01 & 649.08 & $\mathrm{n}=29$ \\
\hline & within & & 241.89 & -400.04 & 1932.22 & T-bar $=18.7931$ \\
\hline \multirow[t]{3}{*}{ GAS } & overall & 83.83 & 140.76 & 0 & 926.23 & $N=557$ \\
\hline & between & & 88.08 & 3.97 & 344.54 & $n=30$ \\
\hline & within & & 109.38 & -255.68 & 745.88 & $\mathrm{~T}$-bar $=18.5667$ \\
\hline \multirow[t]{3}{*}{ GDP } & overall & 5888.6 & 12403.88 & 3.04 & 88652.25 & $N=600$ \\
\hline & between & & 8944.83 & 3.39 & 37769.98 & $n=30$ \\
\hline & within & & 8739.8 & -31084.3 & 57947.1 & $T=20$ \\
\hline \multirow[t]{3}{*}{ SCON } & overall & 34.05 & 13.15 & 3.01 & 73.39 & $N=600$ \\
\hline & between & & 5.95 & 26.31 & 49.62 & $n=30$ \\
\hline & within & & 11.77 & -10.95 & 57.82 & $\mathrm{~T}=20$ \\
\hline \multirow[t]{3}{*}{ SINV } & overall & 47.98 & 23.32 & 0.56 & 98.99 & $N=600$ \\
\hline & between & & 7.74 & 36.56 & 63.75 & $n=30$ \\
\hline & within & & 22.04 & -8.24 & 106.02 & $T=20$ \\
\hline \multirow[t]{4}{*}{ SGOV } & overall & 6.46 & 7.58 & 0 & 46.61 & $N=600$ \\
\hline & between & & 5.64 & 1.82 & 23.15 & $n=30$ \\
\hline & within & & 5.16 & -11.12 & 31.44 & $\mathrm{~T}=20$ \\
\hline & overall & 13.19 & 18.1 & 0.22 & 89.34 & $N=600$ \\
\hline \multirow[t]{2}{*}{ SEXP } & between & & 16.24 & 2.81 & 68.73 & $n=30$ \\
\hline & within & & 8.51 & -45.96 & 58.61 & $\mathrm{~T}=20$ \\
\hline \multirow[t]{3}{*}{ SIMP } & overall & 12.43 & 17.92 & 0.23 & 97.83 & $N=600$ \\
\hline & between & & 15.67 & 2.2 & 64.17 & $n=30$ \\
\hline & within & & 9.13 & -47.3 & 54.95 & $T=20$ \\
\hline \multirow[t]{3}{*}{ URR } & overall & 44.03 & 22.37 & 0.45 & 98.75 & $N=600$ \\
\hline & between & & 13.56 & 28.44 & 83.12 & $n=30$ \\
\hline & within & & 17.96 & -27.64 & 97.67 & $T=20$ \\
\hline \multirow[t]{3}{*}{ REE } & overall & 0.64 & 0.74 & 0 & 7.36 & $N=600$ \\
\hline & between & & 0.56 & 0.01 & 2.46 & $n=30$ \\
\hline & within & & 0.5 & -1.57 & 5.54 & $T=20$ \\
\hline \multirow[t]{2}{*}{ EPR } & overall & 38.05 & 32.34 & 0 & 99.66 & $N=600$ \\
\hline & between & & 4.77 & 29.65 & 52.35 & $\mathrm{n}=30$ \\
\hline
\end{tabular}

Page 5/19 


\begin{tabular}{|lllllll|}
\hline Variable & & Mean & Std. Dev. & Min & Max & Observations \\
\hline & within & & 31.99 & -14.07 & 104.4 & $\mathrm{~T}=20$ \\
\hline EEF & overall & 7.43 & 8.12 & 0 & 54.56 & $\mathrm{~N}=600$ \\
& between & & 2.83 & 2.81 & 12.71 & $\mathrm{n}=30$ \\
\hline & within & & 7.63 & -4.95 & 50.13 & $\mathrm{~T}=20$ \\
\hline
\end{tabular}

The basic relationship between the aforementioned variables are specified as (1), (2), (3), (4), and the similar equations can be seen in Al-Mulali and Che (2012):

$$
\begin{aligned}
& \operatorname{LnTOT}_{i, t}=\beta_{0}+\beta_{1} \operatorname{LnGDP}_{i, t}+\beta_{2} \operatorname{LnSCON}_{i, t}+\beta_{3} \operatorname{LnSINV}_{i, t}+\beta_{4} \operatorname{LnSGOV}_{i, t}+\beta_{5} \operatorname{LnSEXP_{i,t}} \\
& +\beta_{6} \operatorname{LnSIMP}_{i, t}+\beta_{7} \operatorname{LnURR}_{i, t}+\beta_{8} \operatorname{LnREE}_{i, t}+\beta_{9} L n E P R_{i, t}+\beta_{10} \operatorname{LnEEF}_{i, t}+\varepsilon_{i, t} \\
& \operatorname{LnOTH}_{i, t}=\beta_{0}+\beta_{1} \operatorname{LnGDP}_{i, t}+\beta_{2} \operatorname{LnSCON}_{i, t}+\beta_{3} \operatorname{LnSINV}_{i, t}+\beta_{4} \operatorname{LnSGOV}_{i, t}+\beta_{5} \operatorname{LnSEXP}_{i, t} \\
& +\beta_{6} \operatorname{LnSIMP}_{i, t}+\beta_{7} \operatorname{LnURR}_{i, t}+\beta_{8} \operatorname{LnREE}_{i, t}+\beta_{9} \operatorname{LnEPR}_{i, t}+\beta_{10} \operatorname{LnEEF}_{i, t}+\varepsilon_{i, t} \\
& L n C O L_{i, t}=\beta_{0}+\beta_{1} \operatorname{LnGDP}_{i, t}+\beta_{2} \operatorname{LnSCON}_{i, t}+\beta_{3} \operatorname{LnSINV}_{i, t}+\beta_{4} \operatorname{LnSGOV}_{i, t}+\beta_{5} \operatorname{LnSEXP_{i,t}} \\
& +\beta_{6} \operatorname{LnSIMP}_{i, t}+\beta_{7} \operatorname{LnURR}_{i, t}+\beta_{8} \operatorname{LnREE}_{i, t}+\beta_{9} L n E P R_{i, t}+\beta_{10} \operatorname{LnEEF}_{i, t}+\varepsilon_{i, t} \\
& \operatorname{LnOIL}_{i, t}=\beta_{0}+\beta_{1} \operatorname{LnGDP}_{i, t}+\beta_{2} \operatorname{LnSCON}_{i, t}+\beta_{3} \operatorname{LnSINV}_{i, t}+\beta_{4} \operatorname{LnSGOV}_{i, t}+\beta_{5} \operatorname{LnSEXP}_{i, t} \\
& +\beta_{6} \operatorname{LnSIMP}_{i, t}+\beta_{7} \operatorname{LnURR}_{i, t}+\beta_{8} \operatorname{LnREE}_{i, t}+\beta_{9} \operatorname{LnEPR}_{i, t}+\beta_{10} \operatorname{LnEEF}_{i, t}+\varepsilon_{i, t}
\end{aligned}
$$

\section{Correlation Study On Energy Structure And Influencing Factors}

\subsection{National Study}

For panel data, model selection between fixed effects model and random effects model is very important. As the detailed explanation on the model selection is available in many studies (Wooldridge 2002; Lee 2005; Al-Mulali and Che 2012; Apergis and Payne 2009; Gozgor et al. 2018). We only report the results of Hausman test and overidentifying test in order to determine the selection of either random or fixed effects model. This study would use fixed effects model as results affirmed in Table 3. Furthermore, heteroscedasticity, serial correlation and cross-sectional dependence tests are needed. In this paper, a modified Wald statistic for groupwise heteroskedasticity in the residuals is implement, following Greene (2000), and the results are shown in Table 4. The test results of the hypothesis of serial dependence correlation are shown in Table 5, and this method had been discussed by Wooldridge (2002). The hypothesis of crosssectional independence in panel data models with small T and large $\mathrm{N}$ can be implemented with two semi-parametric tests proposed by Friedman (1937) and Frees $(1995,2004)$, as well as the parametric testing procedure proposed by Pesaran (2004). The results are shown in Table 6.

Table 3

Hausman test and Overidentifying test of energy consumption equation of national panel data

\begin{tabular}{|llllll|}
\hline Equation & Equation (1) & Equation (2) & Equation (3) & Equation (4) & Equation (5) \\
\hline Dependent variables & LnTOT & LnOTH & LnCOL & LnOIL & LnGAS \\
\hline Hausman test statistic & 14.57 & 18.95 & 21.48 & 23.35 & 41.44 \\
\hline Prob. & 0.2032 & 0.062 & 0.0287 & 0.0158 & 0 \\
\hline Sargan-Hansen statistic & 18.508 & 64.738 & 41.206 & 26.717 & 47.230 \\
\hline P-value & 0.047 & 0 & 0 & 0.0029 & 0 \\
\hline
\end{tabular}

Table 4

Wald statistic test for groupwise heteroskedasticity

\begin{tabular}{|llllll|}
\hline Equation & Equation (1) & Equation (2) & Equation (3) & Equation (4) & Equation (5) \\
\hline Dependent variables & LnTOT & LnOTH & LnCOL & LnOIL & LnGAS \\
\hline Wald test statistic & 984.04 & 1185.56 & 459.5 & 14019.48 & 2030.9 \\
\hline Prob. & 0 & 0 & 0 & 0 & 0 \\
\hline
\end{tabular}


Table 5

Wooldridge test for autocorrelation in panel data

\begin{tabular}{|llllll|}
\hline Equation & Equation (1) & Equation (2) & Equation (3) & Equation (4) & Equation (5) \\
\hline Dependent variables & LnTOT & LnOTH & LnCOL & LnOIL & LnGAS \\
\hline Wooldridge test statistic & 11.396 & 8.154 & 14.996 & 48.566 & 213.128 \\
\hline Prob. & 0.0082 & 0.0189 & 0.0038 & 0.0001 & 0 \\
\hline
\end{tabular}

Table 6

Test for cross-sectional independence in panel data ${ }^{[1]}$

\begin{tabular}{|llllll|}
\hline Equation & Equation (1) & Equation (2) & Equation (3) & Equation (4) \\
\hline Dependent variables & LnTOT & LnOTH & LnCOL & LnOIL & Equation (5) \\
\hline Pesaran's test & -1.987 & $\mathrm{~N}^{[2]}$ & 1.096 & $\mathrm{~N}$ & -2.818 \\
\hline Prob. & 0.0469 & $\mathrm{~N}$ & 0.273 & $\mathrm{~N}$ & $\mathrm{~N}$ \\
\hline Friedman's test & 13.547 & $\mathrm{~N}$ & 30.008 & $\mathrm{~N}$ & 9.539 \\
\hline Prob. & 0.9934 & $\mathrm{~N}$ & 0.4136 & $\mathrm{~N}$ & 0.9998 \\
\hline Frees' test & 1.312 & $\mathrm{~N}$ & 3.025 & 3.467 \\
\hline
\end{tabular}

Note: [1] Critical values from Frees' Q distribution: 0.10:0.1294; 0.05: 0.1695; 0.01:0.2468. [2]For the equations of other energy consumption and oil consumption, the panels are highly unbalanced, there are not enough common observations across panel to perform the test.

It can be seen that there are different test results for different energy consumption equations, and the data of some equations may have the problem of heteroscedasticity, autocorrelation and cross sectional correlation. To solve these problems, regression with Driscoll-Kraay standard method (Driscoll and Kraay, 1998) is adopted. In order to test whether there is a structural change in this time period, especially after the Asian financial crisis in 1998 and the global financial crisis in 2008 (Wen et al. 2012; Dungey and Zhumabekova 2001), this paper will introduce dummy variables and test the joint significance of all dummy variables and their cross-term coefficients with explanatory variables. That is to say, the dummy variable "d" is introduced in the basic equations (1)(5). After 2008, $d=1$; conversely, $d=0$, and the interaction terms between the dummy variable " $d$ " and each influencing variables are also introduced: $\mathrm{dLnGDP}=\mathrm{d} *$ LnGDP, $\mathrm{dLnSCON}=\mathrm{d} *$ LnSCON,dLnSINV $=\mathrm{d} *$ LnSINV,dLnSGOE $=\mathrm{d}^{*}$ LnSGOE, $\mathrm{dLnSEXP}=\mathrm{d} *$ LnSEXP,

$\mathrm{dLnSIMP}=\mathrm{d}^{*}$ LnSIMP,dLnURR $=\mathrm{d}^{*}$ LnURR,dLnREE $=\mathrm{d} * \mathrm{LnREE}, \mathrm{dLnEPR}=\mathrm{d} *$ LnEPR, and dLnEEF $=\mathrm{d} *$ LnEEF. Table 7 shows that there is indeed a structural change after 2008. We give the coefficient estimates obtained by regressing the data of the two time periods respectively, as shown in Table 8. The regression results of the data from 1998-2017 are also presented in Table 8.

Table 7

Joint significance test of coefficients of dummy variable and its interaction terms with explaining variables

\begin{tabular}{|llllll|}
\hline Dependent variable & LnTOT & LnOTH & LnCOL & LnOIL & LnGAS \\
\hline F(11, 19) & 6.79 & 13.43 & 60.13 & 13.04 & 27.28 \\
Prob $>$ F & 0.0002 & 0 & 0 & 0 & 0 \\
\hline
\end{tabular}

According to the results of Table 8 , from the national situation, the role of income in energy consumption has shown a decline after 2008 , and this result is similar to the research of Mentis et al. (2015) and Sadorsky (2020). The increase in household final consumption expenditure in the income is inhibiting the total energy consumption, while there is a significant positive role in natural gas consumption, and the effect is stronger after 2008; the increase in the proportion of gross capital formation in GDP has a certain forward pulling effect on the total energy consumption, but the role is smaller, and after 2008 the role is not significant. Before 2008 , an increase of this proportion plays a forward role in other energy consumption, but after 2008 , its role becomes negative, and the role on natural gas consumption changes to a significant forward direction; The proportional change in general government final consumption expenditure and change in total energy consumption have reversed relationships, and this effect is no longer significant since 2008. The reverse relationship between the proportional change in government consumption and coal consumption has become more remarkable after 2008, and after 2008 , it has a forward relationship with natural gas consumption; the change in exports has shown a significant reverse relationship with natural gas consumption before 2008. After 2008, it has a significant reverse relationship with oil consumption. According to the data, China has been affected by the global economic situation in 2008, exports account for a reduction in GDP after 2008, and this change has promoted China's oil consumption. After 2008, the proportion of import in China's GDP improved, and it also promoted the increase in China's oil consumption. That is, the comprehensive trade factors in recent years has also shown that China's internal economic cycle is improved. This process may increase the demand for oil consumption during internal transportation.

The urbanization process has a pulling effect on the increase in total energy consumption, but the role is significantly smaller after 2008. For other energy consumption, that is, non-fossil energy consumption, the urbanization process before 2008 shows its inhibitory effect, while after 2008 , the inhibitory effect is no longer significant; On the whole, there is a clear negative relationship between fossil energy security capabilities and natural gas and oil consumption. To a certain extent, it indicates that there is a clear geographic deviation between the distribution of oil and gas resources and the distribution of oil and gas consumption in China. After 2008, the deviation of oil resource distribution and consumption distribution has become more significant, while the deviation of natural gas became smaller. Changes in fuel prices did not restrain total energy consumption. From the perspective of fuel price index, China's fuel prices showed an upward trend during the study period. However, fossil energy consumption was not restrained by prices, and the price elasticity was positive and has increased after 2008. But the changes in fuel prices have also played a significant role in promoting the development of non-fossil energy and the

Page $7 / 19$ 
consumption of natural gas, and there has been no significant change in time. Based on these results, the increase in the fuel price index cannot contribute to energy saving, but it can optimize the energy structure to a certain extent. During the study period, the improvement of energy efficiency had a restraining effect on energy consumption, but according to the staged regression, this effect showed a downward trend.

Table 8

Coefficient estimations of national panel data by time period based on fixed-effects regression with Driscoll-Kraay standard [1]

\begin{tabular}{|c|c|c|c|c|c|c|c|c|c|c|c|c|c|}
\hline $\begin{array}{l}\text { Dependent } \\
\text { Variable }\end{array}$ & LnTOT & & & LnOTH & & & LnCOL & & & LnOlL & & & L \\
\hline $\begin{array}{l}\text { Time } \\
\text { Span }\end{array}$ & $\begin{array}{l}1998- \\
2017\end{array}$ & $\begin{array}{l}1998- \\
2008\end{array}$ & $\begin{array}{l}2009- \\
2017\end{array}$ & $\begin{array}{l}1998- \\
2017\end{array}$ & $\begin{array}{l}1998- \\
2008\end{array}$ & $\begin{array}{l}2009- \\
2017\end{array}$ & $\begin{array}{l}1998- \\
2017\end{array}$ & $\begin{array}{l}1998- \\
2008\end{array}$ & $\begin{array}{l}2009- \\
2017\end{array}$ & $\begin{array}{l}1998- \\
2017\end{array}$ & $\begin{array}{l}1998- \\
2008\end{array}$ & $\begin{array}{l}2009- \\
2017\end{array}$ & $\begin{array}{l}1 \\
2\end{array}$ \\
\hline LnGDP & -0.008 & $0.163^{*}$ & 0.001 & $0.035^{*}$ & 1.178 & 0.009 & -0.018 & $0.237^{*}$ & -0.002 & $-0.026^{*}$ & 0.103 & -0.025 & -( \\
\hline LnVCON & $-0.678^{\star \star \star}$ & $-0.56^{\star \star *}$ & 0.048 & $-3.073^{\star \star \star}$ & $-4.3^{\star *}$ & 0.731 & $-0.838^{* \star *}$ & $-0.772^{* *}$ & $-0.268^{*}$ & $-1.18^{* \star \star}$ & $-1.328^{\star \star \star}$ & 0.048 & -( \\
\hline LnVINV & $0.087^{\star *}$ & 0.02 & -0.013 & 0.214 & $1.263^{\star \star}$ & $-0.419^{*}$ & 0.068 & $-0.102^{* *}$ & -0.017 & -0.061 & -0.106 & 0.018 & -( \\
\hline LnVGOV & $-0.164^{\star \star \star}$ & $-0.208^{\star \star *}$ & -0.048 & 0.251 & -0.274 & 0.657 & $-0.182^{\star * \star}$ & $-0.243^{\star \star \star}$ & 0.103 & -0.179 & -0.086 & 0.088 & $-c$ \\
\hline LnVEXP & -0.038 & 0.052 & -0.005 & 0.299 & -0.067 & $-0.378^{*}$ & 0 & 0.049 & 0.001 & $-0.245^{\star \star \star}$ & -0.089 & -0.132 & -( \\
\hline LnVIMP & $0.055^{* *}$ & $0.087^{\star \star *}$ & $-0.028^{*}$ & -0.444 & -0.113 & 0.082 & $0.053^{\star *}$ & $0.103^{* \star *}$ & 0.045 & $0.286^{\star \star *}$ & 0.044 & $0.23^{*}$ & -1 \\
\hline LnURR & $0.4^{\star \star \star}$ & $0.391^{\star *}$ & $0.072^{*}$ & 0.086 & $-1.157^{\star \star \star}$ & 0.201 & $0.335^{\star \star \star}$ & $0.184^{\star *}$ & $0.172^{\star \star \star}$ & 0.313 & -0.017 & $0.176^{\star \star}$ & -( \\
\hline LnREE & -0.008 & 0.026 & $-0.099^{\star *}$ & -0.147 & 0.186 & -0.036 & 0.007 & -0.051 & -0.023 & $-0.292^{\star \star *}$ & $-0.205^{* *}$ & $-0.424^{\star \star \star}$ & -1 \\
\hline LnEPR & $0.167^{\star \star *}$ & $0.158^{*}$ & $0.605^{\star \star \star}$ & $0.930^{\star \star *}$ & 0.427 & 0.187 & $0.191^{* *}$ & $0.185^{\text {** }}$ & $0.741^{\star * *}$ & $-0.431^{\star \star \star}$ & -0.25 & $0.542^{\star *}$ & 1 \\
\hline LnEEF & $-0.404^{\star \star \star}$ & $-0.310^{\star \star \star}$ & $-0.159^{\star * *}$ & $-0.553^{\star \star *}$ & $-0.73^{\star \star *}$ & -0.185 & $-0.331^{\star * *}$ & $-0.271^{\star * *}$ & $-0.119^{* *}$ & $-0.561^{\star \star \star}$ & $-0.444^{*}$ & $-0.313^{\star \star \star}$ & $\therefore$ \\
\hline _cons & $8.524^{\star \star \star}$ & $6.744^{* \star *}$ & $4.805^{\star \star \star}$ & $8.684^{\star \star \star}$ & 9.978 & -0.269 & $8.867^{\star \star \star}$ & $7.692^{\star \star \star}$ & $3.992^{\star \star}$ & $11.787^{\star \star \star}$ & $11.744^{\star \star \star}$ & 1.592 & 5 \\
\hline
\end{tabular}

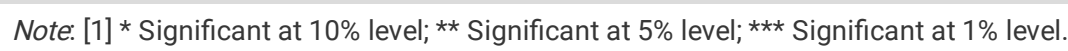

\subsection{Regional Study}

Considering that there are strong geographical characteristics in both consumption and resources distribution of energy in China, a sub-regional analysis is conducted from in this paper. Based on the division of NBSC in 2011, China's mainland can be divided into four major economic regions: east, central, west and northeast, as shown in Table 9.

Table 9

Chinese economic regions division ${ }^{[1]}$

\begin{tabular}{|ll|}
\hline East & Beijing, Fujian, Guangdong, Hainan, Hebei, Jiangsu, Shandong, Shanghai, Tianjin, Zhejiang \\
\hline Middle & Anhui, Henan, Hubei, Hunan, Jiangxi, Shanxi \\
\hline West & Chongqing, Gansu, Guangxi, Guizhou, Inner Mongolia, Ningxia, Qinghai, Shaanxi, Sichuan, Xinjiang, Yunnan \\
\hline North East & Heilongjiang, Jilin, Liaoning \\
\hline $\begin{array}{l}\text { Note: [1] The data sources for this article include provinces in mainland China, and as there is no energy consumption data for Tibet, this region is not } \\
\text { included in the analysis of this paper. }\end{array}$ \\
\hline
\end{tabular}

Table 10

Hausman test of energy consumption equation of regional panel data

\begin{tabular}{|c|c|c|c|c|c|c|}
\hline & Dependent Variable & LnTOT & LnOTH & LnCOL & LnOIL & LnGAS \\
\hline \multirow[t]{2}{*}{ East } & Hausman test statistic & 92.79 & 44.62 & 103.95 & 65.16 & 63.21 \\
\hline & Prob. & 0 & 0 & 0 & 0 & 0 \\
\hline \multirow[t]{2}{*}{ Middle } & Hausman test statistic & 58.79 & 33.34 & 78.8 & 11.06 & 46.35 \\
\hline & Prob. & 0 & 0 & 0 & 0.0259 & 0 \\
\hline \multirow[t]{2}{*}{ West } & Hausman test statistic & 119.32 & 60.97 & 137.09 & 147.48 & 129.44 \\
\hline & Prob. & 0 & 0 & 0 & 0 & 0 \\
\hline \multirow[t]{2}{*}{ North East } & Hausman test statistic & 3.8 & 3.17 & 4.33 & 22.38 & 14.61 \\
\hline & Prob. & 0.1499 & 0.2049 & 0.115 & 0 & 0.0007 \\
\hline
\end{tabular}


Based on the results of Table 10, the Hausman test of total primary energy, coal and other energy consumption in the Northeast is not significant, and the Hausman test of all types of energy consumption in various regions indicates that a fixed effect model should be adopted. Moreover, heteroscedasticity, serial correlation and cross-sectional dependence tests are also presented in Table 11, Table 12, Table 13. For regional panel data in this study, as the data section unit $(\mathrm{N})$ is less than the data time span $(\mathrm{T})$, Breusch-Pagan statistic is better for testing cross-sectional independence in the residuals of a fixed effect regression model, following Greene (2000). Based on the results of Table 11, Table 12, Table 13, as most equations of most energy consumption in most regions have heteroscedasticity, autocorrelation and inter-group correlation problems, regression with Driscoll-Kraay standard method is adopted. Results of Table 14 presented the significance test of coefficients of dummy variable and its interaction terms with explaining variables and indicated that there are structural change in the year of 2008, the coefficient estimates obtained by regressing the data from 1998-2017 and the two time periods of $1998-2008$ and 2009-2017 respectively are shown in Table 15, Table 16, Table 17, and Table 18.

Table 11

Wald statistic test for groupwise heteroskedasticity of regional panel data

\begin{tabular}{|c|c|c|c|c|c|c|}
\hline & Dependent Variable & LnTOT & LnOTH & LnCOL & LnOIL & LnGAS \\
\hline \multirow[t]{2}{*}{ East } & Wald test statistic & 96.46 & 291.51 & 195.38 & 646.36 & 3701.45 \\
\hline & Prob. & 0 & 0 & 0 & 0 & 0 \\
\hline \multirow[t]{2}{*}{ Middle } & Wald test statistic & 49.05 & 1259.37 & 71.83 & 154.93 & 8.43 \\
\hline & Prob. & 0 & 0 & 0 & 0 & 0.2086 \\
\hline \multirow[t]{2}{*}{ West } & Wald test statistic & 340.5 & 236.43 & 69.21 & 4129.43 & 201.26 \\
\hline & Prob. & 0 & 0 & 0 & 0 & 0 \\
\hline \multirow[t]{2}{*}{ North East } & Wald test statistic & 21.5 & 109.32 & 16.5 & 57.77 & 0.04 \\
\hline & Prob. & 0.0001 & 0 & 0.0009 & 0 & 0.9982 \\
\hline
\end{tabular}

Table 12

Wooldridge test for autocorrelation in panel data

\begin{tabular}{|c|c|c|c|c|c|c|}
\hline & Dependent Variable & LnTOT & LnOTH & LnCOL & LnOIL & LnGAS \\
\hline \multirow[t]{2}{*}{ East } & Wooldridge test statistic & 11.396 & 8.154 & 14.996 & 48.566 & 213.128 \\
\hline & Prob. & 0.0082 & 0.0189 & 0.0038 & 0.0001 & 0 \\
\hline \multirow[t]{2}{*}{ Middle } & Wooldridge test statistic & 16.87 & 26.038 & 32.405 & 0.264 & 23.291 \\
\hline & Prob. & 0.0093 & 0.0038 & 0.0023 & 0.6342 & 0.0048 \\
\hline \multirow[t]{2}{*}{ West } & Wooldridge test statistic & 20.547 & 12.551 & 7.085 & 14.019 & 47.883 \\
\hline & Prob. & 0.0011 & 0.0053 & 0.0238 & 0.0046 & 0 \\
\hline \multirow[t]{2}{*}{ North East } & Wooldridge test statistic & 3.789 & 16.037 & 0.01 & 31.108 & 58.606 \\
\hline & Prob. & 0.191 & 0.0571 & 0.9284 & 0.0307 & 0.0166 \\
\hline
\end{tabular}

Table 13

Test for cross-sectional independence in panel data

\begin{tabular}{|lllllll|}
\hline & Dependent Variable & LnTOT & LnOTH & LnCOL & LnOIL & LnGAS \\
\hline East & Breusch-Pagan LM test statistic & 92.574 & 73.364 & 107.164 & 68.184 & 154.023 \\
& Prob. & 0 & 0.0048 & 0 & 0.0144 & 0 \\
\hline Middle & Breusch-Pagan LM test statistic & 16.997 & 24.651 & 23.711 & 5.705 & 31.393 \\
& Prob. & 0.319 & 0.0548 & 0.0702 & 0.8394 & 0.0078 \\
\hline West & Breusch-Pagan LM test statistic & 76.237 & $\mathrm{~N}^{[1]}$ & 93.613 & $\mathrm{~N}^{[1]}$ & 88.172 \\
\hline \multirow{2}{*}{ North East } & Breusch-Pagan LM test statistic & 1.156 & 10.197 & 2.984 & 3.953 & 4.248 \\
\hline & Prob. & 0.0306 & $\mathrm{~N}^{[1]}$ & 0.0009 & $\mathrm{~N}^{[1]}$ & 0.003 \\
\hline \multirow{2}{*}{ Note: $\mathrm{N}$ indicates too few common observations across panel. } & 0.017 & 0.3941 & 0.2666 & 0.2359 \\
\hline
\end{tabular}


Table 14

Joint significance test of coefficients of dummy variable and its interaction terms with explaining variables

\begin{tabular}{|lllllll|}
\hline \multirow{5}{*}{ East } & Equation & LnTOT & LnOTH & LnCOL & LnOIL & LnGAS \\
& $\mathrm{F}(11,19)$ & 11.9 & 26.85 & 6.09 & 93.27 & 7.9 \\
\hline \multirow{2}{*}{ Middle } & Prob $>\mathrm{F}$ & 0 & 0 & 0.0003 & 0 & 0.0001 \\
\hline \multirow{2}{*}{ West } & $\mathrm{F}(11,19)$ & 23.07 & 22.11 & 8.71 & 4.85 & 61.61 \\
\hline \multirow{2}{*}{ North East } & Prob $>\mathrm{F}$ & 0 & 0 & 0 & 0.0013 & 0 \\
& $\mathrm{~F}(11,19)$ & 19.76 & 54.62 & 12.56 & 100.04 & 19.24 \\
& Prob $>\mathrm{F}$ & 0 & 0 & 0 & 0 & 0 \\
\hline
\end{tabular}

According to the results of the regression of the eastern region, income increase is still the driving factor of per capita total energy consumption and coal consumption, while it is not yet a driving factor for non-fossil energy consumption, or even a restraining factor. The increase in the proportion of household consumption in GDP has not become an opportunity for the development of non-fossil energy, and has even become a significant restraining factor after 2008, and it is still a driving factor that promotes the increase in total energy consumption, coal and oil consumption; The increase in the proportion of fixed asset investment significantly increases coal consumption and natural gas consumption in the region; The increase in the proportion of government expenditure has shown a certain inhibitory effect on total energy consumption, but has shown a significant promotion effect on natural gas consumption after 2008; The trade changes in the eastern region are more consistent with the national situation, that is, the proportion of exports in GDP has declined after 2008, while imports have shown an upward trend, and the changes in exports and total energy consumption have an inverse relationship, that is, as the proportion of exports in the eastern region has fallen, per capita total energy consumption increased, non-fossil energy consumption and natural gas consumption increased, coal and oil consumption showed a decrease change; An increase in the proportion of imports can play a role in restraining per capita total energy consumption; Urbanization is also one of the important driving factors of total energy consumption in the eastern region, but the effect is also showing a downward trend. The development of eastern urbanization has even suppressed oil consumption, which may be related to the realization of the relatively higher public transportation network; Most provinces in the eastern region are relatively scarce in fossil resources, and their own fossil energy consumption guarantee capacity is showing a downward trend, which is conducive to the development of non-fossil energy to a certain extent, but it has not become a constraint to restrain its fossil energy consumption; The increase in the fuel price index has not become a factor that restrains total energy consumption. The consumption of oil and coal still rises with the increase in the fuel index, but its promotion of non-fossil energy consumption and natural gas consumption is stronger, and this effect has become more effective after 2008, which shows that although the fuel price index increase cannot play a role in energy saving, it can promote the optimization of the energy structure of the region; In line with national estimates, the effect of energy efficiency improvement on energy conservation is diminishing.

Table 15

Coefficient estimations of East region panel data based on fixed-effects regression with Driscoll-Kraay standard [1]

\begin{tabular}{|c|c|c|c|c|c|c|c|c|c|c|c|c|c|}
\hline $\begin{array}{l}\text { Dependent } \\
\text { Variable }\end{array}$ & LnTOT & & & LnOTH & & & LnCOL & & & LnOIL & & & Ln \\
\hline $\begin{array}{l}\text { Time } \\
\text { Span }\end{array}$ & $\begin{array}{l}1998- \\
2017\end{array}$ & $\begin{array}{l}1998- \\
2008\end{array}$ & $\begin{array}{l}2009- \\
2017\end{array}$ & $\begin{array}{l}1998- \\
2017\end{array}$ & $\begin{array}{l}1998- \\
2008\end{array}$ & $\begin{array}{l}2009- \\
2017\end{array}$ & $\begin{array}{l}1998- \\
2017\end{array}$ & $\begin{array}{l}1998- \\
2008\end{array}$ & $\begin{array}{l}2009- \\
2017\end{array}$ & $\begin{array}{l}1998- \\
2017\end{array}$ & $\begin{array}{l}1998- \\
2008\end{array}$ & $\begin{array}{l}2009- \\
2017\end{array}$ & $\begin{array}{l}19 \\
20\end{array}$ \\
\hline LnGDP & $0.198^{*}$ & 0.071 & $0.136^{* *}$ & 0.152 & 0.508 & $-0.88^{\star * *}$ & 0.297 & -0.129 & $0.242^{*}$ & $0.452^{\star \star}$ & -0.046 & 0.006 & $0 .:$ \\
\hline LnVCON & $-1.135^{\star \star \star}$ & $-0.938^{\star \star \star}$ & -0.101 & -0.635 & $-3.248^{* *}$ & $1.759^{\star \star *}$ & $-1.46^{* \star *}$ & $-0.927^{\star \star \star}$ & -0.423 & $-2.022^{\star \star \star}$ & $-1.446^{* *}$ & $0.794^{* *}$ & $0 .:$ \\
\hline LnVINV & 0.102 & 0.009 & 0.015 & -0.292 & 1.314 & -0.482 & $0.265^{\star \star *}$ & 0.092 & 0.056 & 0.191 & 0.102 & -0.147 & $0 . ؟$ \\
\hline LnVGOV & $-0.203^{* *}$ & $-0.359^{\star * *}$ & $-0.374^{* *}$ & $-1.124^{\star *}$ & $-2.214^{\star \star \star}$ & 0.797 & $-0.429^{\star *}$ & $-0.754^{\star \star *}$ & 0.437 & 0.225 & -0.151 & $-0.427^{*}$ & 0.1 \\
\hline LnVEXP & $-0.165^{\star \star \star}$ & -0.116 & 0.084 & -0.192 & -0.057 & $-1.25^{*}$ & $0.209^{\star \star}$ & $0.129^{*}$ & $0.595^{\star *}$ & $-0.622^{\star \star *}$ & -0.618 & $0.347^{\star \star}$ & -0 . \\
\hline LnVIMP & 0.103 & $0.242^{\star *}$ & $-0.054^{* *}$ & $-0.644^{*}$ & -0.221 & -0.506 & -0.03 & $0.149^{\star * \star}$ & -0.088 & 0.278 & 0.463 & 0.043 & -0 . \\
\hline LnURR & $0.482^{\star \star \star}$ & $0.539^{\star *}$ & $0.129^{\star *}$ & $0.592^{\star \star}$ & $0.873^{*}$ & 0.093 & $0.471^{\star \star *}$ & $0.370^{\star *}$ & $0.243^{*}$ & $0.877^{\star \star \star}$ & $1.053^{*}$ & $-0.19^{\star *}$ & -0 . \\
\hline LnREE & -0.021 & 0.024 & $-0.109^{\star * *}$ & $-0.277^{*}$ & 0.059 & -0.047 & -0.077 & -0.076 & -0.112 & 0.034 & 0.026 & $-0.412^{\star k *}$ & -0 . \\
\hline LnEPR & 0.013 & 0.114 & $0.245^{\star \star \star}$ & 0.307 & 0.334 & $2.058^{\star \star \star}$ & -0.044 & 0.073 & $0.866^{\star * *}$ & -0.197 & 0.112 & $0.461^{\star * *}$ & 1.4 \\
\hline LnEEF & $-0.402^{* \star *}$ & $-0.264^{\star *}$ & $-0.12^{*}$ & $-0.525^{\star \star \star}$ & -0.083 & 0.289 & $-0.173^{\star \star \star}$ & $-0.164^{\star *}$ & -0.02 & $-0.605^{\star \star *}$ & $-0.424^{*}$ & $-0.189^{*}$ & -1. \\
\hline _cons & $9.607^{\star \star \star}$ & $8.725^{\star \star \star}$ & $6.378^{\star \star \star}$ & $7.581^{*}$ & 7.796 & $-3.947^{\star}$ & $8.486^{\star \star *}$ & $9.826^{\star \star \star}$ & -0.997 & $9.429^{\star \star \star}$ & $8.089^{* \star}$ & 1.927 & -2 \\
\hline
\end{tabular}

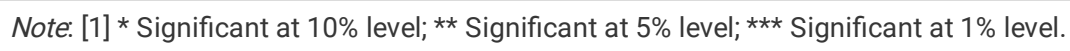


Table 16

Coefficient estimations of Middle region panel data based on fixed-effects regression with Driscoll-Kraay standard ${ }^{[1]}$

\begin{tabular}{|c|c|c|c|c|c|c|c|c|c|c|c|c|c|}
\hline $\begin{array}{l}\text { Dependent } \\
\text { Variable }\end{array}$ & LnTOT & & & LnOTH & & & LnCOL & & & LnOIL & & & LnGAS \\
\hline $\begin{array}{l}\text { Time } \\
\text { Span }\end{array}$ & $\begin{array}{l}1998- \\
2017\end{array}$ & $\begin{array}{l}1998- \\
2008\end{array}$ & $\begin{array}{l}2009- \\
2017\end{array}$ & $\begin{array}{l}1998- \\
2017\end{array}$ & $\begin{array}{l}1998- \\
2008\end{array}$ & $\begin{array}{l}2009- \\
2017\end{array}$ & $\begin{array}{l}1998- \\
2017\end{array}$ & $\begin{array}{l}1998- \\
2008\end{array}$ & $\begin{array}{l}2009- \\
2017\end{array}$ & $\begin{array}{l}1998- \\
2017\end{array}$ & $\begin{array}{l}1998- \\
2008\end{array}$ & $\begin{array}{l}2009- \\
2017\end{array}$ & $\begin{array}{l}1998- \\
2017\end{array}$ \\
\hline LnGDP & 0.013 & $1.299^{\star *}$ & 0.014 & 0.078 & 3.894 & 0.015 & 0.010 & 0.269 & -0.004 & 0.019 & 0.910 & $0.026^{*}$ & $0.117^{\star}$ \\
\hline LnVCON & $-0.622^{*}$ & 0.317 & 0.539 & -2.413 & $-3.223^{*}$ & 0.311 & $-1.029^{\star * \star}$ & $-1.257^{\star \star \star}$ & $0.597^{\star \star}$ & $-1.085^{* \star}$ & -1.808 & -0.849 & $-4.937^{* *}$ \\
\hline LnVINV & $0.210^{\star *}$ & 0.039 & 0.186 & 0.885 & -0.511 & 0.507 & -0.075 & -0.005 & $-0.149^{*}$ & -0.005 & -0.024 & 0.275 & $1.578^{*}$ \\
\hline LnVGOV & -0.137 & 0.056 & -0.586 & 0.844 & $3.226^{\star \star}$ & -1.767 & 0.127 & $0.192^{* *}$ & 0.266 & 0.030 & 0.444 & -0.821 & $2.767^{\star \star \star}$ \\
\hline LnVEXP & 0.062 & $0.269^{*}$ & -0.050 & $0.929^{\star \star *}$ & 0.066 & 0.629 & 0.080 & $0.236^{\star * *}$ & -0.153 & $0.267^{\star \star \star}$ & -0.004 & 0.132 & -0.152 \\
\hline LnVIMP & $-0.116^{* *}$ & 0.009 & -0.009 & 0.133 & 0.843 & 0.299 & -0.029 & -0.069 & 0.059 & $-0.183^{*}$ & -0.217 & $-0.193^{* *}$ & -0.683 \\
\hline LnURR & 0.127 & 0.014 & -0.185 & 0.334 & -0.446 & 0.450 & 0.203 & -0.052 & -0.067 & 0.325 & 0.574 & 0.320 & $1.672^{\star *}$ \\
\hline LnREE & $-0.142^{*}$ & 0.135 & $-0.276^{* *}$ & -0.208 & 0.168 & 0.150 & -0.020 & 0.013 & -0.049 & -0.190 & -0.362 & -0.091 & $0.514^{*}$ \\
\hline LnEPR & 0.215 & 0.122 & 0.335 & 0.178 & 0.662 & $-2.697^{*}$ & $0.35^{*}$ & 0.259 & $0.77^{* *}$ & -0.095 & -0.214 & -0.267 & 0.734 \\
\hline LnEEF & $-0.425^{* \star *}$ & -0.244 & $-0.342^{* *}$ & $-0.911^{*}$ & 0.17 & $-0.875^{\star \star *}$ & $-0.277^{\star \star *}$ & -0.245 & -0.074 & 0.054 & 0.301 & $-0.389^{\star * *}$ & $-1.552^{\text {* }}$ \\
\hline _cons & $8.371^{\text {k*k}}$ & -7.430 & $5.88^{\star \star \star *}$ & 3.132 & -32.941 & 15.684 & $8.838^{\text {k*k}}$ & 7.771 & 2.059 & $7.043^{\star \star \star}$ & -0.462 & $9.266^{*}$ & 1.977 \\
\hline
\end{tabular}

Note: [1] * Significant at $10 \%$ level; ** Significant at $5 \%$ level; *** Significant at $1 \%$ level.

Table 17

Coefficient estimations of West region panel data based on fixed-effects regression with Driscoll-Kraay standard ${ }^{[1]}$

\begin{tabular}{|c|c|c|c|c|c|c|c|c|c|c|c|c|c|}
\hline $\begin{array}{l}\text { Dependent } \\
\text { Variable }\end{array}$ & LnTOT & & & LnOTH & & & LnCOL & & & LnOIL & & & Lnc \\
\hline $\begin{array}{l}\text { Time } \\
\text { Span }\end{array}$ & $\begin{array}{l}1998- \\
2017\end{array}$ & $\begin{array}{l}1998- \\
2008\end{array}$ & $\begin{array}{l}2009- \\
2017\end{array}$ & $\begin{array}{l}1998- \\
2017\end{array}$ & $\begin{array}{l}1998- \\
2008\end{array}$ & $\begin{array}{l}2009- \\
2017\end{array}$ & $\begin{array}{l}1998- \\
2017\end{array}$ & $\begin{array}{l}1998- \\
2008\end{array}$ & $\begin{array}{l}2009- \\
2017\end{array}$ & $\begin{array}{l}1998- \\
2017\end{array}$ & $\begin{array}{l}1998- \\
2008\end{array}$ & $\begin{array}{l}2009- \\
2017\end{array}$ & $\begin{array}{l}199 \\
201\end{array}$ \\
\hline LnGDP & $-0.021^{* *}$ & 0.168 & 0.003 & 0.012 & $1.581^{\star *}$ & 0.049 & $-0.04^{\star * *}$ & $0.199^{* *}$ & $-0.021^{* *}$ & $-0.055^{\star \star *}$ & $1.013^{\star *}$ & -0.003 & -0.0 \\
\hline LnVCON & $-0.483^{*}$ & -0.415 & 0.393 & $-3.894^{\star \star *}$ & -0.248 & $-2.762^{\star *}$ & -0.346 & -0.564 & -0.063 & $-2.801^{\star * *}$ & -1.913 & -0.217 & -1.8 \\
\hline LnVINV & 0.028 & 0.014 & -0.020 & 0.738 & $2.191^{\star *}$ & -0.263 & -0.05 & -0.085 & 0.024 & -0.233 & 0.041 & 0.057 & -0.3 \\
\hline LnVGOV & $-0.359^{\star \star \star}$ & $-0.36^{\star \star \star}$ & -0.025 & -0.11 & -0.623 & 1.606 & $-0.286^{\star \star \star}$ & $-0.309^{\star \star *}$ & -0.137 & -0.443 & 0.158 & 0.026 & -0.0 \\
\hline LnVEXP & -0.062 & 0.095 & -0.097 & $1.226^{\star \star *}$ & 0.364 & 0.497 & $-0.122^{\star \star \star}$ & -0.036 & -0.123 & $-0.262^{\star *}$ & 0.155 & -0.767 & -0.5 \\
\hline LnVIMP & 0.065 & 0.016 & 0.024 & -0.025 & -0.193 & 0.118 & $0.065^{* \star *}$ & 0.044 & 0.075 & 0.140 & 0.095 & 0.718 & $0.3:$ \\
\hline LnURR & 0.108 & 0.086 & -0.004 & $-1.228^{\star *}$ & $-2.483^{*}$ & -0.455 & 0.204 & $0.496^{* * *}$ & 0.035 & -0.624 & $-4.064^{\star \star *}$ & $1.066^{\star * *}$ & -0.3 \\
\hline LnREE & 0.010 & 0.022 & -0.070 & 0.441 & 1.076 & -0.160 & 0.036 & -0.028 & -0.011 & $-0.922^{\star \star *}$ & -0.357 & -1.017 & -0.4 \\
\hline LnEPR & $0.559^{\star \star \star}$ & $0.424^{*}$ & $1.394^{\star * *}$ & 0.14 & 0.717 & -0.948 & $0.52^{\star \star \star}$ & $0.345^{\star *}$ & $0.751^{\star * *}$ & $-0.726^{*}$ & -0.624 & 1.115 & 0.81 \\
\hline LnEEF & $-0.361^{\star \star \star}$ & $-0.377^{\star \star \star}$ & $-0.145^{\star \star}$ & $-1.024^{\star \star \star}$ & $-1.705^{*}$ & -0.094 & $-0.384^{\star \star \star}$ & $-0.274^{\star \star *}$ & $-0.363^{\star *}$ & $-0.793^{\star \star \star}$ & $-1.268^{*}$ & -0.094 & -1.0 \\
\hline _cons & $8.007^{\star \star \star k}$ & $6.63^{\star \star *}$ & 0.213 & $18.044^{\star \star \star ~}$ & -7.745 & 14.705 & $7.47^{\star \star \star}$ & $5.726^{\star * \star}$ & $5.092^{* *}$ & $24.084^{\text {** }}$ & $21.025^{\star *}$ & -4.695 & 12.: \\
\hline
\end{tabular}


Table 18

Coefficient estimations of North East region panel data based on fixed-effects regression with Driscoll-Kraay standard [1]

\begin{tabular}{|c|c|c|c|c|c|c|c|c|c|c|c|c|c|}
\hline $\begin{array}{l}\text { Dependent } \\
\text { Variable }\end{array}$ & LnTOT & & & LnOTH & & & LnCOL & & & LnOIL & & & Ln \\
\hline $\begin{array}{l}\text { Time } \\
\text { Span }\end{array}$ & $\begin{array}{l}1998- \\
2017\end{array}$ & $\begin{array}{l}1998- \\
2008\end{array}$ & $\begin{array}{l}2009- \\
2017\end{array}$ & $\begin{array}{l}1998- \\
2017\end{array}$ & $\begin{array}{l}1998- \\
2008\end{array}$ & $\begin{array}{l}2009- \\
2017\end{array}$ & $\begin{array}{l}1998- \\
2017\end{array}$ & $\begin{array}{l}1998- \\
2008\end{array}$ & $\begin{array}{l}2009- \\
2017\end{array}$ & $\begin{array}{l}1998- \\
2017\end{array}$ & $\begin{array}{l}1998- \\
2008\end{array}$ & $\begin{array}{l}2009- \\
2017\end{array}$ & $\begin{array}{l}19 \\
20\end{array}$ \\
\hline LnGDP & $0.843^{*}$ & 0.665 & 0.173 & 6.277 & $31.481^{\star \star \star}$ & -4.976 & $1.153^{\star \star}$ & $1.688^{\star *}$ & 0.663 & $-0.871^{*}$ & $-1.958^{\star \star \star}$ & 0.553 & $2 . \varepsilon$ \\
\hline LnVCON & -0.303 & -0.438 & $0.227^{\star \star \star}$ & $-5.52^{\star \star}$ & 1.979 & -2.433 & -0.120 & -0.603 & $0.395^{\star * \star}$ & -0.289 & -0.517 & -0.035 & -0 \\
\hline LnVINV & -0.046 & -0.260 & 0.042 & -0.598 & $4.323^{*}$ & -2.910 & -0.014 & 0.030 & $0.208^{\star \star *}$ & -0.043 & $-0.354^{* *}$ & -0.066 & -0 . \\
\hline LnVGOV & 0.021 & 0.046 & -0.035 & $2.950^{\star \star}$ & -1.364 & 0.946 & 0.147 & -0.058 & 0.059 & $-0.235^{\star *}$ & -0.624 & 0.161 & -0 . \\
\hline LnVEXP & 0.039 & -0.079 & $-0.035^{*}$ & $-1.867^{*}$ & -1.48 & -1.320 & $-0.266^{\star * *}$ & -0.190 & -0.045 & 0.046 & -0.022 & $-0.092^{\star \star *}$ & -0 . \\
\hline LnVIMP & 0.146 & 0.045 & $-0.08^{\star \star *}$ & -0.465 & 3.348 & -0.665 & $0.249^{*}$ & $0.419^{\star}$ & $-0.101^{*}$ & -0.006 & -0.154 & 0.050 & -0. \\
\hline LnURR & $0.568^{\star \star *}$ & 0.637 & -0.047 & 1.804 & -4.627 & 0.235 & 0.086 & -0.165 & $0.095^{*}$ & -0.001 & 0.076 & 0.108 & -0 . \\
\hline LnREE & -0.108 & $-0.564^{* \star *}$ & 0.007 & 1.198 & 2.733 & 0.296 & 0.048 & 0.029 & $0.106^{\star \star *}$ & -0.074 & -0.255 & 0.025 & $0 . c$ \\
\hline LnEPR & 0.129 & 0.090 & $0.588^{\star \star \star}$ & 0.865 & 0.273 & 1.172 & $0.356^{* *}$ & 0.151 & $0.603^{\star \star *}$ & $0.149^{*}$ & $0.121^{*}$ & $0.254^{*}$ & 0.9 \\
\hline LnEEF & $-0.213^{* *}$ & -0.332 & -0.009 & -0.543 & -3.496 & 0.416 & $-0.187^{*}$ & -0.091 & -0.032 & -0.105 & -0.355 & $-0.083^{*}$ & -0 . \\
\hline _cons & 0.226 & 3.194 & $3.54^{\text {** }}$ & -30.116 & $-200.416^{\star *}$ & 52.216 & -2.057 & -2.548 & -2.239 & $13.708^{\star \star \star \star}$ & $25.125^{\star \star k}$ & 1.224 & -9. \\
\hline
\end{tabular}

Note: [1] * Significant at $10 \%$ level; ** Significant at $5 \%$ level; *** Significant at $1 \%$ level.

The increase in income levels in the central region does not seem to be the main driving factor for energy consumption; during the study period, the proportion of household final consumption in the region has risen and fallen. According to coefficient estimates, the increase in the proportion of household final consumption will reduce the total per capita primary energy consumption, but it will increase the coal consumption; The increase in the proportion of fixed asset investment in GDP will significantly increase per capita primary energy consumption and natural gas consumption in the region; The increase in the proportion of government consumption has a positive effect on non-fossil energy consumption, but the effect is no longer significant after 2008 , and the promotion effect on natural gas consumption is still relatively significant; Different from the development of trade in the nation and the eastern region, the proportion of exports and imports in this region increased during the study period. According to the coefficient estimates, the increase in exports promoted the development of non-fossil energy consumption and oil consumption, and after 2008, natural gas consumption has been significantly increased. The increase in the proportion of imports has a certain inhibitory effect on primary energy consumption and oil consumption, but the effect is small, and after 2008, natural gas consumption has also been significantly increased. Overall, the increase in trade level has positive significance for energy conservation and emission reduction in the region; The promotion of energy consumption by urbanization in this region is mainly reflected in natural gas consumption; The energy resource endowment of the central region is also relatively lacking, but it has not inhibited its primary energy consumption, and as its fossil energy security capacity decreases, primary energy consumption has been greatly increased after 2008; Compared with the whole country and the eastern region, the improvement of energy efficiency in this region still has a greater potential for energy conservation.

The increase in income levels in the western region seems to have become a factor in restraining energy consumption, which is not in line with the level and stage of its economic development. The increase in the proportion of household final consumption in GDP is a powerful energy-saving factor; The increase in the proportion of fixed asset investment in this region was significant during the study period. It was a driving factor for the development of non-fossil energy before 2008, but for natural gas consumption, investment was a restraining factor; Government consumption was also a restraining factor for primary energy and coal consumption before 2008; In terms of import and export, the proportion of imports and exports of western provinces has risen and fallen. The increase in exports has a very positive effect on increasing non-fossil energy consumption and reducing fossil energy consumption. The increase in the proportion of imports has a boosting effect on natural gas consumption; The development of urbanization does not seem to be beneficial to the consumption of non-fossil energy in the region, but the impact of this unfavorable factor is weakening. In addition, the development of urbanization has a significant role in promoting oil and natural gas consumption; The western region has strong fossil energy security capabilities and is the main source of fossil energy consumption in the country. However, the increase in resource security capabilities in the region has a clear reverse relationship with oil and natural gas consumption, indicating that more oil and gas have been shipped to the central and eastern regions; Rising fuel prices have not become a factor in restraining energy consumption in the region, and even have a significant promotion effect on coal consumption, and it has not promoted the development of non-fossil energy; the energy-saving effect of energy efficiency improvement in the region has also declined as a whole.

Increasing income in the Northeast is still one of the main driving factors for its energy consumption, but this effect is decreasing. Increase in income has a restraining effect on oil consumption, but this effect is also decreasing; The increase in the proportion of household consumption will increase primary energy consumption and curb non-fossil energy consumption; The increase in the proportion of fixed asset investment in the region was conducive to the development of non-fossil energy before 2008, but after 2008 it has significantly promoted the consumption of coal; The increase in the proportion of government expenditure in the region is conducive to the development of non-fossil energy and has a certain restraining effect on natural gas consumption; During the study period, the proportion of exports in the region has dropped significantly, and the proportion of imports has risen overall. According to the coefficient estimates, the decline in exports is not conducive to energy conservation, and the rise in the proportion of imports will significantly increase coal 
consumption, that is, the development of trade in the region lacks positive significance for energy conservation and emission reduction; Urbanization in this area is the main driving factor of per capita primary energy consumption, and its effects seem to have not undergone significant structural changes; Historically, the region's fossil energy resource security capability was strong, and it has shown a downward trend in recent years. The decline in resource security capacity before 2008 has an inverse relationship with its per capita primary energy consumption. After 2008, the decline in resource security capacity has a certain inhibitory effect on its per capita coal consumption. The increase in fuel prices has not suppressed the consumption of fossil energy in the region, nor has it promoted the consumption of non-fossil energy; The improvement of energy efficiency in this region is relatively small compared with other regions, and there is no obvious structural change as a whole.

\section{Conclusions And Policy Implications}

Whether it is the study of national panel data or the research of panel data by region, the results show that the decomposition of per capita GDP from the perspective of expenditure method has different effects on energy consumption. At the same time, energy consumption of different type responses to the influencing factors differently, and the impact of the global financial crisis on the economic situation also makes it have a structural transformation effect.

For the whole country, China has been affected by the global economic situation in 2008 , and the role of income in energy consumption has shown a decline in recent years, which means that energy consumption is tending to decouple from GDP. The comprehensive trade factors in recent years has also shown that China's internal economic cycle is improved. This process may increase the demand for oil consumption during internal transportation. The pulling effect on total energy consumption of urbanization has also become smaller after 2008 . For non-fossil energy consumption, the urbanization process before 2008 shows its inhibitory effect, while after 2008, the inhibitory effect is no longer significant; There is a clear geographic deviation between the distribution of oil and gas resources and the distribution of consumption in China. After 2008, the deviation of oil resource distribution and consumption distribution has become more significant, while the deviation of natural gas became smaller. Based on these results, the increase in the fuel price index cannot contribute to energy saving, but it can optimize the energy structure to a certain extent. During the study period, the improvement of energy efficiency had a restraining effect on energy consumption, but according to the staged regression, this effect showed a downward trend.

Considering that there are strong geographical characteristics in both consumption and resources distribution of energy in China, a sub-regional analysis is also conducted. According to the results of the regression of different regions and periods, it is found that income increase is still the driving factor of per capita total energy consumption and coal consumption in East, in the Northeast it is also the main driving factors for energy consumption, but this effect is decreasing. The increase in income levels in the central region does not seem to be the main driving factor for energy consumption, and in the western region it seems to have become a factor in restraining energy consumption, which is not in line with the level and stage of its economic development. Increase in income has a restraining effect on oil consumption in Northeast, and this effect is also decreasing.

In the Eastern part, the increase in the proportion of household consumption in GDP is still a driving factor that promotes the increase in per capita total primary energy consumption, coal and oil consumption, and in Northeast it increase primary energy consumption, and in Central region it will increase the coal consumption; the increase in the proportion of household final consumption in Central region will reduce the total per capita primary energy consumption and in western region it is also a powerful energy-saving factor; in East and Northeast: the increase in the proportion of household final consumption has even become a significant restraining factor in non-fossil energy consumption.

The increase in the proportion of gross capital formation in GDP significantly increases coal consumption and natural gas consumption in the Eastern region; and significantly increases per capita primary energy consumption and natural gas consumption in the central region, after 2008 it has significantly promoted the consumption of coal in northeast; in western region and northeast, the increase in the proportion of gross capital formation was a driving factor for the development of non-fossil energy before 2008.

The increase in the proportion of government consumption expenditure has shown a certain inhibitory effect on per capita total primary energy consumption in East and in West (before 2008), and it was also a restraining factor for coal consumption before 2008 in West; it has shown a significant promotion effect on natural gas consumption in Central, and in East (after 2008), and has a positive effect on non-fossil energy consumption in Northeast and in Central (before 2008).

The trade changes in the eastern region are more consistent with the national situation, that is, the proportion of exports in GDP has declined after 2008, while imports have shown an upward trend; Different from the development of trade in the country and the eastern region, the proportion of exports and imports in Central increased during the study period. The proportion of imports and exports of western provinces has risen and fallen. Summarizing the trade status and energy structure changes in the above three regions, the change in trade situations has positive significance for energy conservation and emission reduction. While in Northeast, during the study period, the proportion of exports in the region has dropped significantly, and the proportion of imports has risen overall. According to the coefficient estimates, the decline in exports is not conducive to energy conservation, and the rise in the proportion of imports will significantly increase coal consumption, that is, the development of trade in the region lacks positive significance for energy conservation and emission reduction.

Urbanization one of the important driving factors of total energy consumption in the eastern region, but the effect is showing a downward trend. And the development of eastern urbanization has even suppressed oil consumption, which may be related to the realization of the relatively higher public transportation network; The promotion of energy consumption by urbanization in Central is mainly reflected in natural gas consumption; The development of urbanization does not seem to be beneficial to the consumption of non-fossil energy development in western region, but the impact of this unfavorable factor is weakening. In addition, the development of urbanization has a significant role in promoting oil and natural gas consumption in western region; Urbanization in Northeast is the main driving factor of per capita primary energy consumption, and its effects seem to have not undergone significant structural changes.

Page $13 / 19$ 
In eastern region, although the fuel price index increase cannot play a role in energy saving, it can promote the optimization of the energy structure of the region; in central, western region and Northeast, rising fuel prices has not suppressed the consumption of fossil energy in the region, nor has it promoted the consumption of non-fossil energy; In line with national estimates, the effect of energy efficiency improvement on energy conservation is diminishing in eastern and western region. The improvement of energy efficiency in Central still has a greater potential for energy conservation. In Northeast, The improvement of energy efficiency in this region is relatively small compared with other regions, and there is no obvious structural change as a whole.

The above results have their policy implications. Since fixed asset investment and government spending as the main driving force for economic development, in the process of investment and government budgeting, attention should be paid to the impact on fossil energy, and guidance in promoting the development of non-fossil energy and energy-saving technologies. On the whole, an increase in the proportion of household consumer consumption in GDP is conducive to energy conservation and emission reduction. Although there are certain differences in the trade development model of various regions in China, the overall development is in the direction of conducive to energy conservation and optimization of the energy structure. Regarding the trade model of the Northeast, it is necessary to further study whether it follows the comparative advantage in the use of energy resources. China is still in the rapid development stage of urbanization, and its own development may be a driving force for the consumption of fossil energy, which is not conducive to the development of non-fossil energy. Therefore, it is of great practical value to explore the urbanization process of clean development. For the whole country and many regions, the overall price increase and fossil energy resources constraints seem to have little effect on fossil energy consumption, but they will also promote non-fossil energy consumption.

\section{Declarations}

\section{Funding}

This work was supported by the National Natural Science Foundation of China (Grant numbers 72173046, 72174113 and 71603086).

\section{Competing Interests}

The authors have no relevant financial or non-financial interests to disclose.

\section{Author Contributions}

All authors contributed to the study conception and design. Jianghua Liu and Ting Wang are mainly responsible for material preparation, data collection and analysis. The first draft of the manuscript was written by Jianghua Liu and mainly revised by Yongqiang Xu and all authors commented on previous versions of the manuscript. All authors read and approved the final manuscript.

\section{Ethical Approval}

No ethics related information.

\section{Consent to Participate}

I am free to contact any of the people involved in the research to seek further clarification and information.

\section{Consent to Publish}

This manuscript has not been published or presented elsewhere in part or in entirety and is not under consideration by another journal.

\section{Availability of data and materials}

The datasets are available from the corresponding author on reasonable request.

\section{References}

1. Al-Mulali U, Che NBCS (2012) The impact of energy consumption and CO2 emission on the economic and financial development in 19 selected countries. Renewable \& Sustainable Energy Reviews 16:4365-4369

2. Apergis N, Payne JE (2009) Energy consumption and economic growth in Central America: Evidence from a panel cointegration and error correction model. Energy Econ 31:211-216

3. Aydin G (2014) Modeling of energy consumption based on economic and demographic factors: The case of Turkey with projections. Renewable \& Sustainable Energy Reviews 35:382-389

4. Bilgen S (2014) Structure and environmental impact of global energy consumption. Renewable \& Sustainable Energy Reviews 38:890-902

5. Chang J, Leung DYC, Wu CZ, Yuan ZH (2003) A review on the energy production, consumption, and prospect of renewable energy in China. Renewable \& Sustainable Energy Reviews 7:453-468

6. Chong CH, Pei L, Ma L, Zheng L, Ni W, Xu L, Song S (2017) LMDI decomposition of energy consumption in Guangdong Province, China, based on an energy allocation diagram. Energy 133:525-544

7. Fan Y, Liao H, WEI Y (2007) Can market oriented economic reforms contribute to energy efficiency improvement? Evidence from China. Energy Policy 35:2287-2295 
8. Fan Y, Xia Y (2012) Exploring energy consumption and demand in China. Energy 40:23-30

9. Feng T, Sun L, Zhang Y (2009) The relationship between energy consumption structure, economic structure and energy intensity in China. Energy Policy $37: 5475-5483$

10. Fisher-Vanden K, Jefferson GH, Liu H, Tao Q (2004) What is driving China's decline in energy intensity? Resource \& Energy Economics 26:77-97

11. Li G, Yamaguchi D, Lin H, Nagai M (2006) "The Simulation Modeling About The Developments of GDP, Population and Primary Energy Consumption in China Based on MATLAB," IEEE Conference on Cybernetics and Intelligent Systems, 2006, pp. 1-6, doi: 10.1109/ICCIS.2006.252244

12. Gozgor G, Chi KML, Zhou L (2018) Energy consumption and economic growth: New evidence from the OECD countries. Energy 153:27-34

13. Kankal M, Akpınar A, Kömürcü M, Özşahin TŞJAE (2011) Modeling and forecasting of Turkey's energy consumption using socio-economic and demographic variables. Appl Energy 88:1927-1939

14. Lee CC (2005) Energy consumption and GDP in developing countries: A cointegrated panel analysis. Energy Econ 27:415-427

15. Li F, Dong S, Li X, Liang Q, Yang W (2011) Energy consumption-economic growth relationship and carbon dioxide emissions in China. Energy Policy 39:568-574

16. Li K, Lin B (2015) Impacts of urbanization and industrialization on energy consumption/CO 2 emissions: Does the level of development matter? Renewable \& Sustainable Energy Reviews 52:1107-1122

17. Liao H, Wei YM (2010) China's energy consumption: A perspective from Divisia aggregation approach. Energy 35:28-34

18. Mahalingam B, Orman WH (2018) GDP and energy consumption: A panel analysis of the US. Appl Energy 213:208-218

19. Narayan PK, Popp S (2012) The energy consumption-real GDP nexus revisited: Empirical evidence from 93 countries. Econ Model 29:303-308

20. NBSC (2018a) China Energy Statistical Yearbook 2017. National Bureau of Statistics of China

21. NBSC (2018b) China Statistical Yearbook 2017. National Bureau of Statistics of China

22. NBSC (2018c) National Accounts. National Bureau of Statistics of China http://data.stats.gov.cn/easyquery.htm?cn=C01

23. Oh W, Lee K (2004) Energy consumption and economic growth in Korea: testing the causality relation. J Policy Model 26:973-981

24. Omri A (2014) An international literature survey on energy-economic growth nexus: Evidence from country-specific studies. Renewable \& Sustainable Energy Reviews 38:951-959

25. Park JH, Hong TH (2013) Analysis of South Korea's economic growth, carbon dioxide emission, and energy consumption using the Markov switching model. Renewable \& Sustainable Energy Reviews 18:543-551

26. Saboori B, Sulaiman J (2013) Environmental degradation, economic growth and energy consumption: Evidence of the environmental Kuznets curve in Malaysia. Energy Policy 60:892-905

27. Tsai SB (2016) Using grey models for forecasting China's growth trends in renewable energy consumption. Clean Technologies \& Environmental Policy 18:563-571

28. Tugcu CT, Topcu M (2018) Total, renewable and non-renewable energy consumption and economic growth: Revisiting the issue with an asymmetric point of view.Energy 152

29. Wandji YDF (2013) Energy consumption and economic growth: Evidence from Cameroon. Energy Policy 61:1295-1304

30. Wang T, Lin B (2017) China's natural gas consumption peak and factors analysis: a regional perspective. J Clean Prod 142:548-564

31. Wang T, Lin B (2019) Fuel consumption in road transport: A comparative study of China and OECD countries. J Clean Prod 206:156-170

32. Wei YM, Liao H, Fan Y (2007) An empirical analysis of energy efficiency in China's iron and steel sector. Energy 32:2262-2270

33. Yuan C, Liu S, Fang Z, Xie N (2010) The relation between Chinese economic development and energy consumption in the different periods. Energy Policy 38:5189-5198

34. Yuan JH, Kang JG, Zhao CH, Hu ZG (2008) Energy consumption and economic growth: Evidence from China at both aggregated and disaggregated levels. Energy Econ 30:3077-3094

35. Zhang H, Lahr ML (2014). "China's Energy Consumption Change from 1987 to 2007: A Multiregional Structural Decomposition Analysis., " Energy Policy 67:682-693

36. Zhang XP, Cheng XM (2009) Energy consumption, carbon emissions, and economic growth in China. Ecol Econ 68:2706-2712

37. Zhou Z, Wu W, Wang X, Chen Q, Wang O (2009) Analysis of changes in the structure of rural household energy consumption in northern China: A case study. Renewable \& Sustainable Energy Reviews 13:187-193

38. Zou G, Chau KW (2006) Short- and long-run effects between oil consumption and economic growth in China. Energy Policy 34:3644-3655

39. Zoundi Z (2017) CO2 emissions, renewable energy and the Environmental Kuznets Curve, a panel cointegration approach. Renew Sustain Energy Rev 72:1067-1075

\section{Figures}




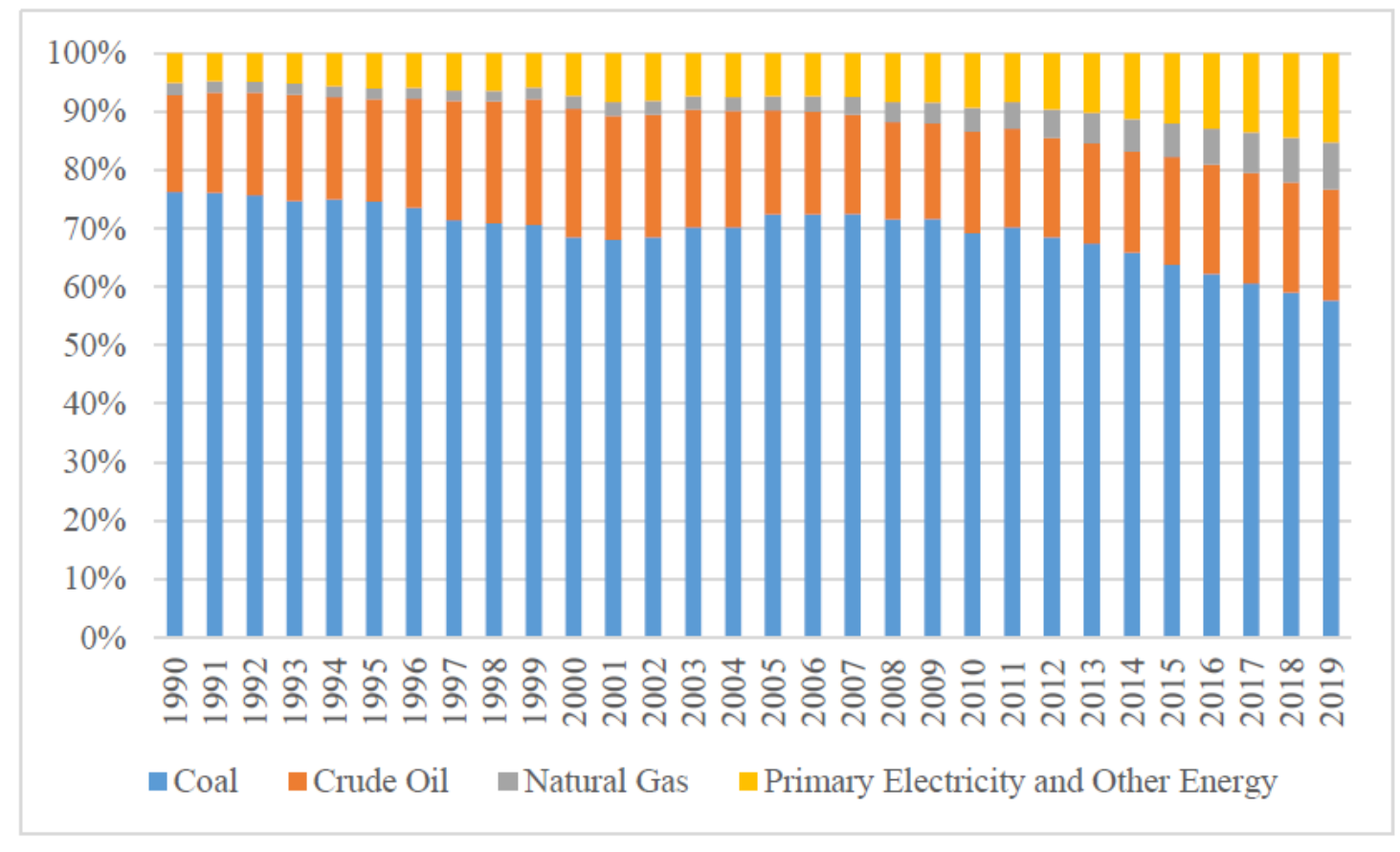

Figure 1

China's primary energy consumption structure

Sources: NBSC (2018b)
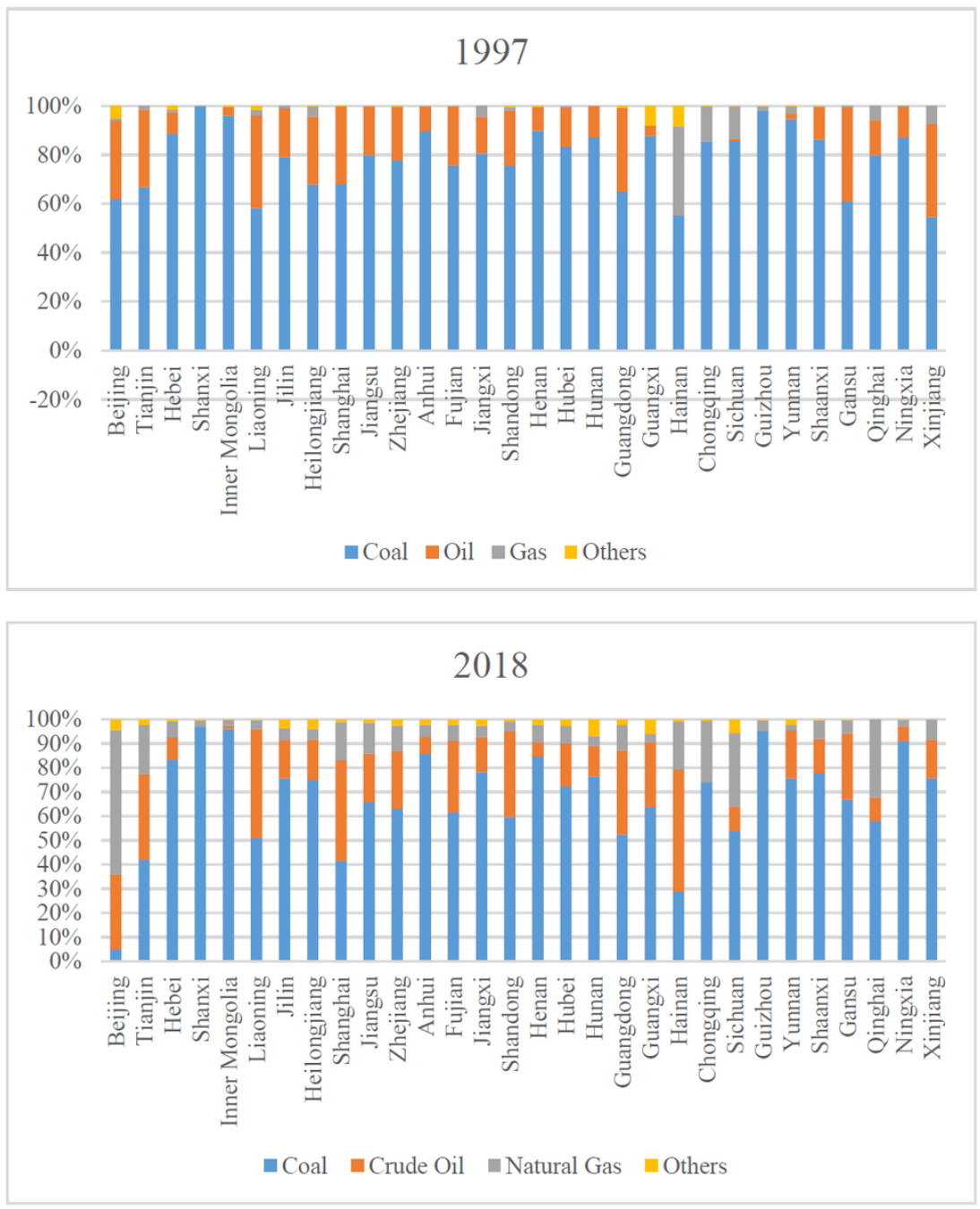

Page 16/19 
Figure 2

Primary energy consumption structure of China's 30 provinces in 1997and 2018

Sources: NBSC (2018a)

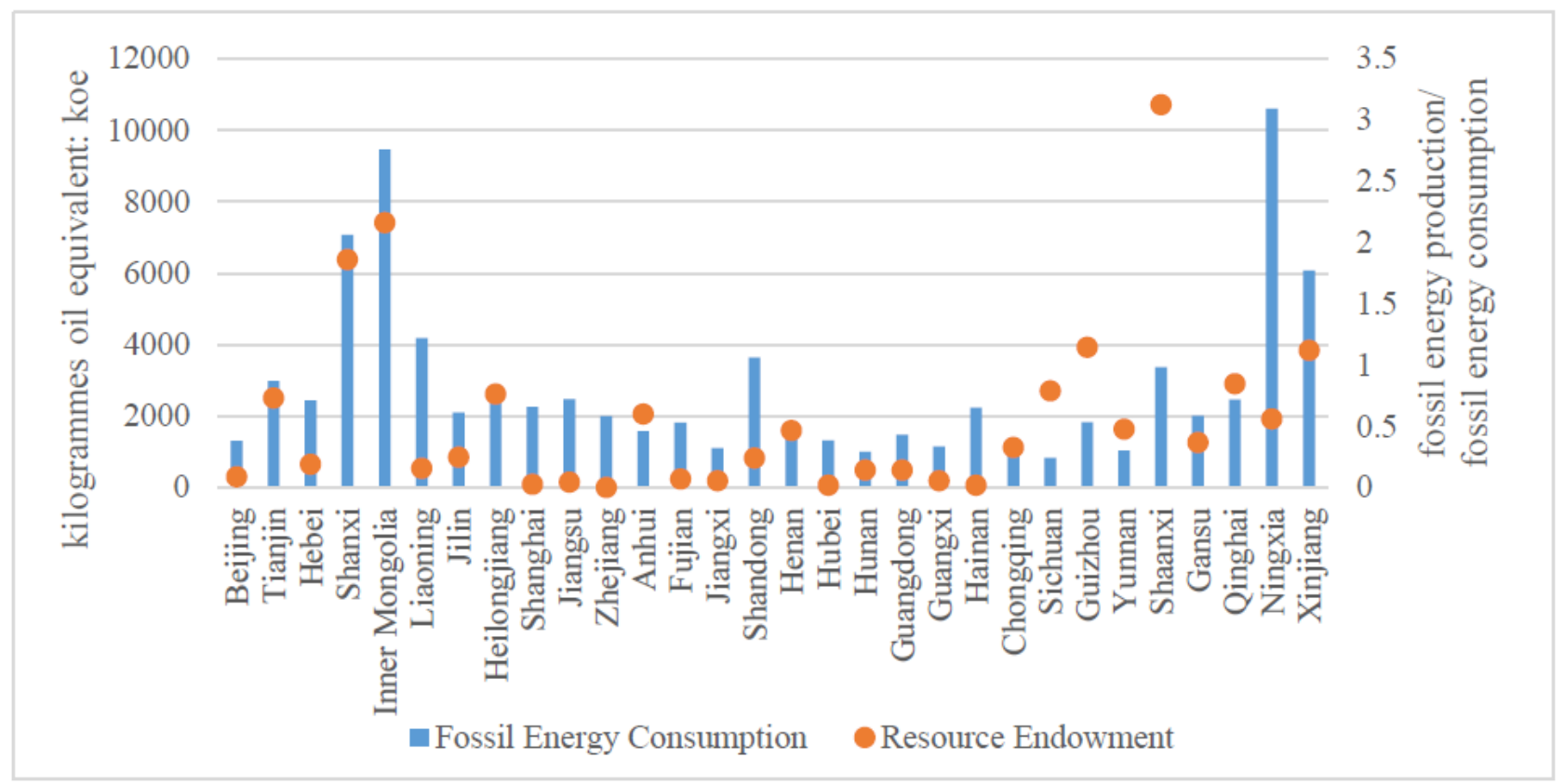

Figure 3

Per capita fossil energy consumption and fossil resource endowment coefficient in China's provinces in $2018^{[1]}$

Sources: NBSC (2018a)

Note: [1] The fossil resource endowment coefficient here is a simple indicator of the energy supply capacity of the fossils in the region, and equals to fossil energy production/fossil energy consumption. 

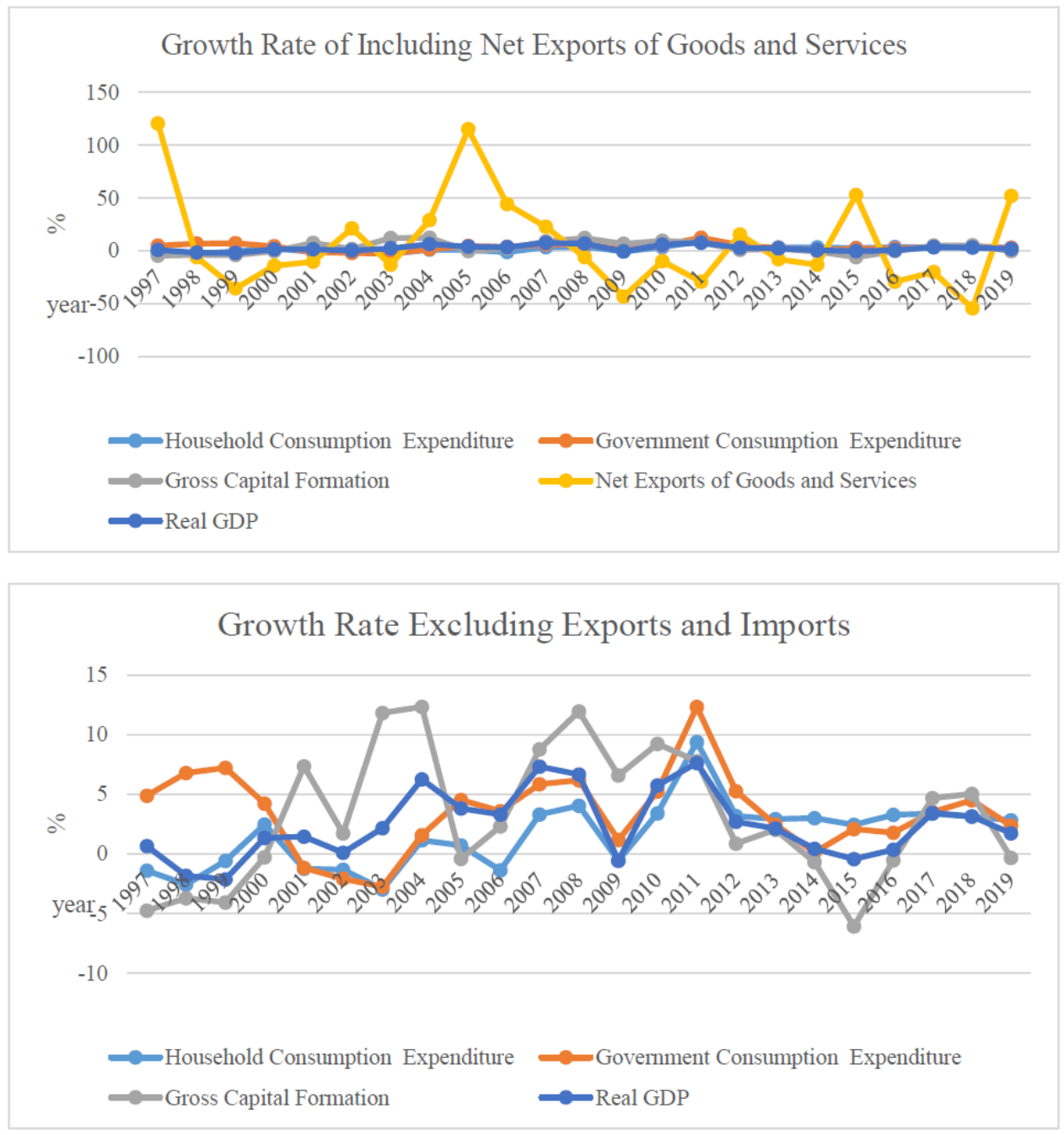

\section{Figure 4}

Growth Rate of Components of Per capita Real GDP by Expenditure Method ${ }^{[1]}$ 


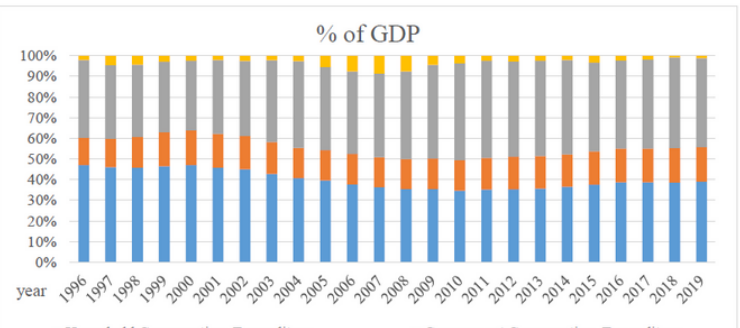

Figure 5

Percentage of Components of Per capita Real GDP by Expenditure Method ${ }^{[1]}$

Sources: NBSC (2018a)

Note: [1] It should be noted that the National Bureau of Statistics of China also indicated in the statistical data of various provinces that due to the adoption of hierarchical accounting, the total GDP of each region does not add up to the national total. 